Article

\title{
Impacts on Metabolism and Gill Physiology of Darter Species (Etheostoma spp.) That Are Attributed to Wastewater Effluent in the Grand River
}

\author{
Rhiannon Hodgson, Leslie Bragg, Hadi A. Dhiyebi@, Mark R. Servos and Paul M. Craig * \\ Department of Biology, University of Waterloo, 200 University Ave W, Waterloo, ON N2L 3G1, Canada; \\ rmhodgso@uwaterloo.ca (R.H.); leslie.bragg@uwaterloo.ca (L.B.); hdhiyebi@uwaterloo.ca (H.A.D.); \\ mservos@uwaterloo.ca (M.R.S.) \\ * Correspondence: paul.craig@uwaterloo.ca
}

Received: 30 October 2020; Accepted: 20 November 2020; Published: 25 November 2020

\begin{abstract}
The effluent from municipal wastewater treatment plants is a major point source of contamination in Canadian waterways. The improvement of effluent quality to reduce contaminants, such as pharmaceuticals and personal care products, before being released into the environment is necessary to reduce the impacts on organisms that live in the river downstream. Here, we aimed to characterize the metabolic and gill physiological responses of rainbow (Etheostoma caeruleum), fantail (Etheostoma flabellare), and greenside (Etheostoma blennioides) darters to the effluent in the Grand River from the recently upgraded Waterloo municipal wastewater treatment plant. The routine metabolism of darters was not affected by effluent exposure, but some species had increased maximum metabolic rates, leading to an increased aerobic scope. The rainbow darter aerobic scope increased by 2.2 times and the fantail darter aerobic scope increased by 2.7 times compared to the reference site. Gill samples from effluent-exposed rainbow darters and greenside darters showed evidence of more pathologies and variations in morphology. These results suggest that darters can metabolically adjust to effluent-contaminated water and may also be adapting to the urban and agricultural inputs. The modification and damage to the gills provide a useful water quality indicator but does not necessarily reflect how well acclimated the species is to the environment due to a lack of evidence of poor fish health.
\end{abstract}

Keywords: Etheostoma species; wastewater effluent; field metabolic rate; gill pathology; respirometry; pharmaceuticals

\section{Introduction}

In the Grand River, located in Southwestern Ontario, contaminant inputs from effluent discharged by municipal wastewater treatment plants (MWWTPs) enter the water and have effects on the fish populations living downstream from the outfall. The effluent post-treatment contains contaminants of emerging concern (CECs), such as pharmaceuticals and personal care products (PPCPs), endocrine-disrupting compounds (EDCs), and other substances that can cause sub-lethal effects [1,2]. In past studies, effects on reproduction, growth, sex ratios, metabolism, and molecular signatures have all been identified as maladaptive phenotypes in downstream locations from MWWTPs in this area, which were attributed to effluent exposure [3-5]. Rainbow darters downstream from the MWWTPs in the Grand River have experienced changes in gene expression, skewed sex ratios, altered gonad size, and intersex or feminized fish populations are found, largely due to the presence of EDCs [6,7]. Additionally, run-off from urban developments and intense agricultural areas, along with stormwater drainages, are other sources of contamination and water quality degradation $[8,9]$. Due to 
increasing human populations, urbanization, and agriculture processes, in combination with climate change, water quality downstream from MWWTPs is at risk and may lead to impacts on the ecology of the river.

MWWTPs receive waste that contains mixed solids, inorganic, and organic contaminants, and treatment is meant to minimize the concentration of contaminants that are released back into the water. Initially, the waste is put through a primary treatment step to settle solids that will move to digestion and form biosolids. Liquids are moved to a secondary treatment, which decreases the biological oxygen demand (BOD) and nitrogenous compounds. The final step, the tertiary treatment, is more filtration or oxidation and is the most valuable step to limit contaminants and nutrients that will be released as a final effluent back into the river system. The tertiary treatment step is not a required process but many facilities are upgrading to incorporate tertiary treatment when upgrading to the required secondary treatment levels and comply with federal and provincial legislation [10,11]. Recently, the Waterloo MWWTP has undergone upgrades to improve the water quality, i.e., reduce ammonia, biological oxygen demand, total suspended solids, and chloride, by increasing the solids retention time and nitrification/aeration [6,12]. Water quality parameters, such as temperature, total suspended solids (TSS), BOD, chlorine, un-ionized ammonia and nitrogen compounds, conductivity, total phosphates, and $\mathrm{pH}$ extremes are all found to be highest or the most variable immediately downstream from MWWTPs and become diluted further downstream $[8,13,14]$. Increased TSS, BOD, and turbidity from effluent increase the water temperature and hypoxia, due to increased sunlight absorption and metabolism of microorganisms causing eutrophication $[13,15]$. Un-ionized ammonia and nitrogen compounds can impact the ability of organisms to survive and reproduce in their environment due to direct toxicity. Damage to gill tissue, $\mathrm{pH}$ imbalances, osmo- and oxy-regulatory transport disruption, and immunocompromising are all possible effects of exposure to increased levels of un-ionized ammonia and nitrogen compounds, with the effects being amplified when exposed to multiple stressors $[16,17]$.

The upgrades greatly reduced the concentrations of many chemicals, Srikanthan et al. [12] reported that concentrations of numerous CEC's remain detectable in the treated effluent, including EDCs (synthetic hormones, personal care products), SSRIs (selective serotonin reuptake inhibitors, i.e., antidepressants), analgesics and anti-inflammatories (non-steroidal anti-inflammatory drugs (NSAIDs), beta-blockers, antiepileptics) [12]. The remaining mixture of contaminants may have the potential to continue to alter ecosystem health and the extent of these effects are largely unknown because of the complexity of the effluent mixtures [18]. There exist provincial guidelines on the limits of concentrations of known contaminants (Provincial Water Quality Objectives) in the surface waters, which were set, in part, to minimize the disruption to aquatic life. The upgrades help to reach or exceed these guidelines by causing a reduction in the concentration of chemicals and contaminants in the effluents, but there are still many CECs that remain in the discharged effluent that can affect aquatic life $[12,18]$. The guideline list includes organics, pesticides, and heavy metals, but does not include CECs that are hard to degrade or settle into biomass, with the possibility of being taken up into the body. Fish, as keystone species, can serve as bioindicators to help assess the health of ecosystems [19], but the effects of wastewater on the physiology of different fish species in rivers, such as the Grand River is currently limited $[19,20]$. Although extensive studies have been conducted on rainbow darter in the Grand River in response to treatment plant upgrades, few studies have examined the effects of treated effluent on the physiology of a group of closely related species with varying degrees of tolerance [6].

Some species can maintain a homeostatic balance in stressful environments better than others, but not without consequence. When a fish encounters a stressor (e.g., contaminant), a general adaptation response occurs, where alarm, resistance, and exhaustion phases may progress [21]. A fish will undergo a stress response, which includes altering its metabolism via energy substrate mobilization due to cortisol release, for example, due to increased energy demand of the gills for detoxification [22]. However, fish can be attracted to and live downstream of WWTPs, likely because 
there is an increase in nutrients, which allows for increased energy toward growth and reproduction, as demonstrated by the increased body condition downstream from MWWTPs, despite the presence of harmful contaminants $[5,23,24]$. A valuable endpoint to measure the effects of chronic exposure to contaminants is the metabolic rate, partly due to this late role in the stress response and its indicator of overall animal health [25]. In fish, aerobic scope (AS) is the difference between the maximum metabolic rate (MMR) and the routine metabolic rate (RMR); it is a measure of external environmental effects on fish and internal compensation and adjustment [26]. RMR is the minimum amount of energy required for physiological life and maintenance; major movement (swimming, food gathering, predator avoidance), growth, and reproduction require additional energy up to the maximum amount of oxygen uptake, i.e., the MMR. In the field, the field metabolic rate (FMR) is measured, which is typically higher than the RMR due to a shorter acclimation period and unknown feeding status [27]. Measuring differences in AS to understand the impacts of an environmental stressor, such as MWWTP effluent, can provide insights into how species are compensating for exposure to these stressors in wastewaters. While Mehdi et al. demonstrated a negative impact on the metabolic rate in rainbow darters, there has not been a cross-species comparison on the impacts of municipal effluent on metabolic rate [4].

In addition to metabolism, the gills are an ideal organ to study effluent effects, as they control several homeostatic functions at the whole animal level (e.g., respiration and ionoregulation) and are at the interface between the internal and external environment of the organism. There is a significant metabolic cost to respiration (10-70\%), and less so for osmoregulation (2-4\%), which can increase when a fish needs to divert energy toward the essential processes [28]. The gill surface can be changed either by being restructured when undergoing an osmorespiratory compromise or in poor water quality conditions to avoid becoming damaged [29]. Damage to the gills is important because it can have effects on the key functions of the organ, such as respiration, osmoregulation, acid-base regulation, and nitrogen excretion. Studies on gill physiology have looked at the impacts of different environmental stressors by looking at changes in the structure, enzyme activity, and expression of the gill [30,31]. In the gills, effluent from MWWTP can cause damage to DNA, increase the gill surface area, and affect the ability to regulate waste [32-34]. Gill damage can cause changes in gill structure, often found in the form of epithelial lifting, hyperplasia/hypertrophy of the gill surface, fusion of secondary lamellae, or gill aneurysms, all of which can be visualized using histological techniques $[16,35,36]$. In this study, the gills were used to look for markers of sublethal damage due to MWWTP effluent and determine whether recent MWWTP upgrades have decreased the amount of damage and restructuring the gills undergo in this environment.

The objectives of this study were to measure whole-body metabolism and changes in gill physiology of darters downstream from the MWWTP to determine whether the darters had increased metabolic demands and altered gill physiology in response to their exposure to effluents after the upgrades. Three darter species, namely, rainbow darter (RBD, Etheostoma caeruleum), fantail darter (FTD, Etheostoma flabellare), and greenside darter (GSD, Etheostoma blennioides), each having slightly different life histories and ecological niches, were selected for this study. The RBD has been used as a sentinel species in many studies in the Grand River due to its small body size, high abundance, and small movement patterns, but few studies have contrasted the effects on other related darter species $[4,23,37]$.

\section{Materials and Methods}

In July 2019 (summer 2019) and October 2019 (fall 2019), samples of the three darter species were collected from sites surrounding the Waterloo MWWTP (US1, US2, DS1, and DS2) to capture seasonal differences in darter responses (Figure 1). All animal use and collection was approved by the University of Waterloo Animal Care Committee and followed the guidelines of animal use from the Canadian Council of Animal Care (Animal Use Protocols: \#40315; \#40318; \#40989). Additionally, archived gill samples that were available from fish collected in October 2013 and 2014 (prior to MWWTP upgrades) were used for comparison between pre- and post-upgrades. US1 and US2 were upstream 
from the Waterloo MWWTP. US1 $\left(43^{\circ} 35^{\prime} 07.54^{\prime \prime} \mathrm{N}, 80^{\circ} 28^{\prime} 54.08^{\prime \prime} \mathrm{W}\right)$ was located upstream from urban development and was an agriculturally dominated area, US2 $\left(43^{\circ} 30^{\prime} 17.41^{\prime \prime} \mathrm{N}, 80^{\circ} 28^{\prime} 28.61^{\prime \prime} \mathrm{W}\right)$ was in an urban area. DS1 $\left(43^{\circ} 28^{\prime} 24.69^{\prime \prime} \mathrm{N}, 80^{\circ} 28^{\prime} 23.99^{\prime \prime} \mathrm{W}\right)$ was immediately downstream from the MWWTP. DS2 $\left(43^{\circ} 26^{\prime} 40.2^{\prime \prime} \mathrm{N}, 80^{\circ} 24^{\prime} 02.7^{\prime \prime} \mathrm{W}\right)$ was approximately $10.5 \mathrm{~km}$ downstream from DS1 and was also in an urban area.

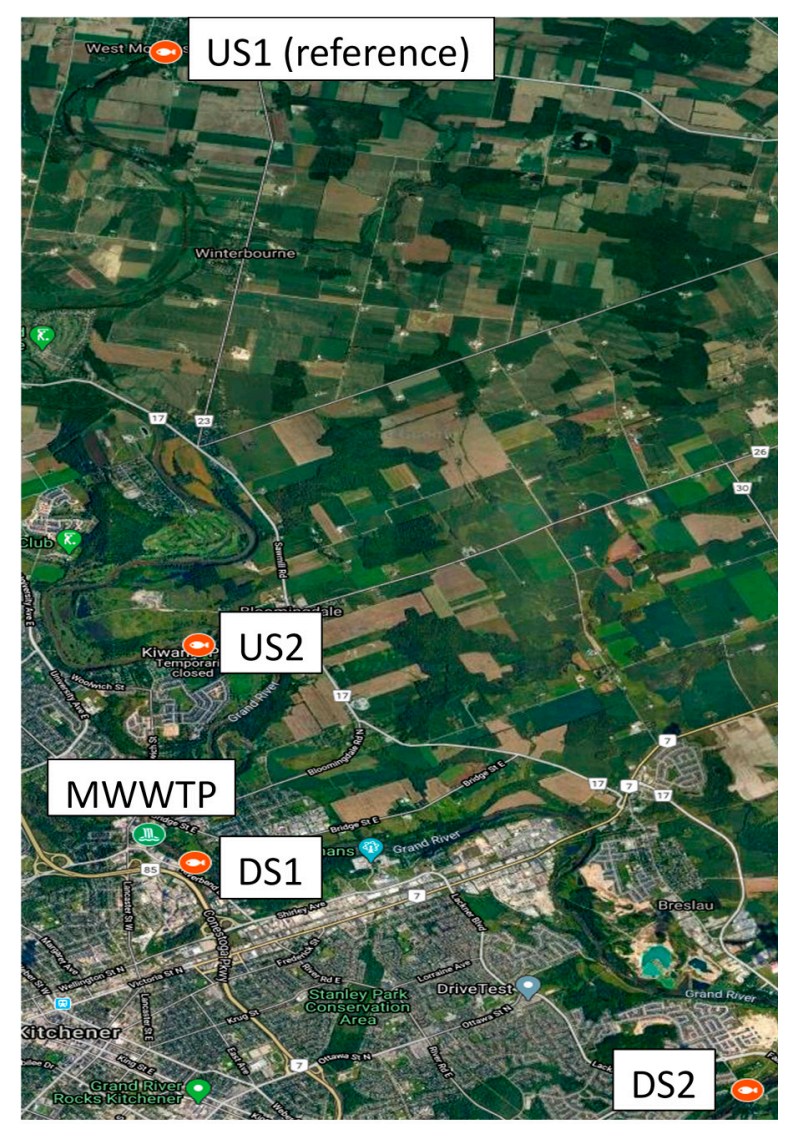

Figure 1. Map of the sampling locations used for collecting the darters used for this study. Orange markers indicate the general locations of capture, green indicates the general location of the effluent outfall. US1, upstream 1; US2, upstream 2; MWWTP, municipal wastewater treatment plant; DS1, downstream 1; DS2, downstream 2 (Google MyMaps; Map data @2020, CNES/Airbus, First Base Solutions, Landsat/Copernicus, Maxar Technologies).

At least 14 random samples of each fish species (RBD, GSD, FTD) were collected in the morning (starting at 9 a.m.) using a backpack electro-fisher and dip nets; they were then placed into buckets that were aerated and kept at river temperature. In fall 2019, no female GSDs were collected. Animal collections were approved by the Animal Care Committee at the University of Waterloo under AUPP\#40318. Fish smaller than $4.0 \mathrm{~cm}$ were not included, as they were previously found to be immature. Fish were used for respirometry trials (detailed below) only in the summer and fall of 2019. Following the respirometry, the fish were measured for total length $( \pm 0.1 \mathrm{~cm})$ and weight $( \pm 0.01 \mathrm{~g})$ and sacrificed via spinal severance. Body condition $(k)$ was calculated using $k=m /\left(l^{3}\right) \times 100$, where $m$ is the mass of fish in grams and $l$ is the length in $\mathrm{cm}$. Fish were then dissected immediately on-site for gill samples in all seasons. The second and third gill arches were extracted directly into Davidson's solution (0.0065 mM formalin, $0.0066 \mathrm{mM} 95 \%$ ethanol, $0.0011 \mathrm{mM}$ glycerol, $0.0017 \mathrm{mM}$ glacial acetic acid) for histological processing.

At each site, water quality measurements (temperature, dissolved oxygen, conductivity, total dissolved solids, $\mathrm{pH}$, and turbidity) were taken using a YSI Proplus multimeter (YSI Incorporated, Yellow Springs, OH, USA). In summer 2019, grab samples of river water were collected in $125 \mathrm{~mL}$ 
amber glass bottles for the analysis of nutrients and pharmaceuticals and general contaminants using LC-MS techniques, as previously described by Fuzzen et al. [5]. Samples of river water $(250 \mathrm{~mL})$ were preserved using $1 \mathrm{~mL} 49 \%$ sulfuric acid and measured for concentrations of total ammonia, nitrite, and nitrate by Maxxam Analytics (Mississauga, ON, Canada).

Intermittent flow respirometry was used to quantify the FMR and MMR in the field following capture. Eight $65 \mathrm{~mL}$ chambers, one reserved for background respiration, were used to measure fish respiration. Water was pumped directly from the river to the reservoir and an open-loop pump moved water through the chambers and out of the reservoir; this was a modified setup like that found in Mochnacz et al. (see Appendix A Figure A1) [38]. When the open-loop pump was turned off, each chamber maintained its flow using a closed-loop pump to mix water and measure oxygen via a fiber optic oxygen probe for continuous measurements (PyroScience, Aachen, Denmark). Fish were placed in the chamber with the circulation of water from the reservoir to prevent hypoxia throughout the acclimation. The fish acclimated for 60 min since no change in FMR was observed after the acclimation of this duration. FMR was then measured for $10 \mathrm{~min}$ after the open-loop pump was turned off, with measurements being taken every second (modified from Mehdi et al. [4]). The MMR was measured by holding fish out of water for two minutes and immediately placing fish into the respirometer where the initial decline in $\mathrm{O}_{2}$ is the MMR. This was modified from the chase protocol due to darters not reacting to being chased [39]. The average temperature of each run was used to correct the measurements of FMR and MMR to $20^{\circ} \mathrm{C}$ for comparison using:

$$
B / M_{20}{ }^{\circ} \mathrm{C}=B / M t e^{\propto(1 / 20-1 / t)},
$$

where $t$ is the body (water) temperature and $\alpha(-5.02)$ is the slope of the line for fish for the equation comparing the effects of temperature to the mass normalized metabolic rate [40]. Trials started at 9:30 a.m. and lasted until approximately 3 p.m. each day, spreading out the use of each species throughout the day to minimize the effects of diurnal fluctuations. There was no significant effect of sex on the metabolic rate when data were separated. Additionally, there were low sample numbers; therefore, samples were pooled together for greater power $(<4 \%$ of the variance in all species).

Gill tissue was examined histologically for changes in morphology and evidence of pathologies at all sites, using US1 as the reference site. Archived gill samples from RBDs in October of 2013 and 2014 were used for comparison as a pre-upgrade reference. Gill tissue was fixed in Davidson's solution for $24 \mathrm{~h}$, then moved to $70 \%$ ethanol. Samples were embedded in paraffin wax, sliced at $5 \mu \mathrm{m}$ until whole gill arches, filaments, and lamellae were seen, and then stained using an automated hematoxylin and eosin stain procedure. Images of the gills were captured using a Leica microscope (DM 1000 LED) and camera (MC170 HD) at 100× using Leica Application Suite (LAS version 10) software (Nußloch, Stuttgart, Germany). A random image was taken of the gill section that had at least three primary filaments present with interior cartilage visible to standardize the location of analysis. Images were randomized and measured blindly. The morphological assessment used was described by Tetreault et al. [41]. Each image had nine measurements of secondary lamellar length (SLL), secondary lamellar width/diameter (SLW), inter-lamellar diameter (ID), and basal epithelium thickness (BET) each, spread along the base, middle, and distal edge of the filament. Measurements were taken using the software Fiji (Fiji Is Just ImageJ version 1) [42]. Gills were scored for pathologies, using a scale from 1-4 on five gill pathologies to assess the degree of damage in the gill tissue (see Appendix A Table A1 and Figure A2). Hypertrophy is the increase in an individual cell's volume, hyperplasia is cell proliferation, epithelial lifting is the peeling of the epithelium from the sinus of the gill, fusion is the (complete or partial) connecting of secondary lamellae, and edema of the lamellae is the enlargement of the sub-epithelium spaces. The gill scoring was modified from Poleksic and Mitrovic-Tutundzic [43]. Scores of all pathologies were summed and the average total score for samples at that site and species was compared to the reference site for each species.

Data were analyzed using the statistical software GraphPad Prism 8 (San Diego, CA, USA). Sex differences were calculated for body measurements but not for metabolic rate due to low $n$ numbers. 
Figures present the data as means \pm standard error of the mean (SEM). Each species-site group was compared using a two-way analysis of variance (two-way ANOVA) separated by season. The data were tested for equal variance and normality with Levine's test and the Kolmogorov-Smirnov test, respectively, to determine whether they met the assumptions of an ANOVA. Dunnett's multiple comparisons test was used to compare each species-site group to the reference site (US1) of the respective species to limit comparisons to a reference site that was largely unaffected by urbanization. Alpha was set at $p<0.05$.

\section{Results}

\subsection{Water Quality}

The water quality measurements in the Grand River are recorded in Table 1 . The means \pm standard error of the mean (SEM) were calculated from three measurements at each site (Tables 1 and 2, Figure 2). Missing values were due to probe calibration issues on that day. In summer 2019, there was an increase in the values at DS1 when compared to US1, which sometimes continued downstream. In the fall, US2 had changes in conditions when compared to US1 (Table 1). Temperature measurements usually varied daily. In fall 2019, ammonia, nitrite, nitrate, conductivity, and chloride concentrations (see Table 2) increased downstream from the MWWTP with detectable levels of ammonia, i.e., $0.10 \mathrm{mg} / \mathrm{L}$, at both DS1 and DS2 relative to reference sites.

Table 1. A summary of the water conditions during the sampling of fishes. Data are presented as mean \pm standard error of the mean (SEM; $n=3$ per site). Water quality measurements were taken on the same day as the sampling at that site where fish were collected from. Total dissolved solids (TDS) and pH in summer 2019 and dissolved oxygen (DO; mg/L) measurements from fall 2019 were unavailable due to instrument calibration issues on the day of sampling. An asterisk indicates a significant difference in concentration compared to US1 (Dunnett's multiple comparisons test, $p<0.05$ ). NTUs, nephelometric turbidity units; US1, upstream 1; US2, upstream 2; MWWTP, municipal wastewater treatment plant; DS1, downstream 1; DS2, downstream 2.

\begin{tabular}{|c|c|c|c|c|c|c|c|}
\hline Season & Site & Temp $\left({ }^{\circ} \mathrm{C}\right)$ & DO $(\mathrm{mg} / \mathrm{L})$ & $\begin{array}{c}\text { Avg. } \\
\text { Conductivity } \\
(\mu \mathrm{S} / \mathrm{cm})\end{array}$ & TDS (ppm) & $\mathrm{pH}$ & $\begin{array}{c}\text { Turbidity } \\
\text { (NTUs) }\end{array}$ \\
\hline \multirow{4}{*}{$\begin{array}{l}\text { Summer } \\
2019\end{array}$} & US1 & $23.47 \pm 0.03$ & $7.39 \pm 0.03$ & $384.70 \pm 0.26$ & $275.60 \pm 0.00$ & $8.37 \pm 0.03$ & $5.07 \pm 0.28$ \\
\hline & US2 & $23.035 \pm 0.03$ & $* 8.43 \pm 0.09$ & $422.83 \pm 0.41$ & - & - & $4.75 \pm 0.66$ \\
\hline & DS1 & $24.52 \pm 0.03$ & * $12.86 \pm 0.20$ & $* 627.33 \pm 27.88$ & $* 416.00 \pm 18.39$ & $8.39 \pm 0.00$ & $4.68 \pm 0.56$ \\
\hline & DS2 & $25.27 \pm 0.07$ & $* 10.10 \pm 0.18$ & $* 512.33 \pm 4.84$ & $* 346.67 \pm 3.54$ & $8.56 \pm 0.04$ & $4.35 \pm 0.21$ \\
\hline \multirow{4}{*}{$\begin{array}{l}\text { Fall } \\
2019\end{array}$} & US1 & $9.10 \pm 0.19$ & - & $268.10 \pm 1.08$ & $251.02 \pm 0.49$ & $8.5 \pm 0.0$ & $3.34 \pm 0.48$ \\
\hline & US2 & $* 11.53 \pm 0.07$ & - & $* 373.07 \pm 0.40$ & * $326.52 \pm 0.47$ & $8.46 \pm 0.0$ & $6.90 \pm 0.76$ \\
\hline & DS1 & $9.20 \pm 0.05$ & - & * $479.57 \pm 7.17$ & $* 446.12 \pm 6.80$ & $* 7.48 \pm 0.1$ & $5.43 \pm 0.23$ \\
\hline & DS2 & $9.07 \pm 0.05$ & - & $* 351.77 \pm 2.03$ & $295.45 \pm 27.23$ & $8.33 \pm 0.0$ & $3.50 \pm 0.14$ \\
\hline
\end{tabular}

Table 2. Summary of total ammonia, nitrite, nitrate, and chloride concentrations at sites where fish were collected during this study in fall 2019. Data are presented as mean \pm SEM ( $n=3$ per site). Concentrations were only available from the fall 2019 sampling period. The values show that there were increased, measurable amounts of nitrogenous compounds and chloride downstream from the MWWTP. An asterisk indicates a significant difference in concentration compared to US1 (Dunnett's multiple comparisons test, $p<0.05$ ). US1, upstream 1; US2, upstream 2; MWWTP, municipal wastewater treatment plant; DS1, downstream 1; DS2, downstream 2.

\begin{tabular}{ccccc}
\hline $\begin{array}{c}\text { Site } \\
\text { Fall 2019 }\end{array}$ & $\begin{array}{c}\text { Ammonia } \\
(\mathbf{m g} / \mathbf{L})\end{array}$ & $\begin{array}{c}\text { Nitrite } \\
(\mathbf{m g} / \mathbf{L})\end{array}$ & $\begin{array}{c}\text { Nitrate } \\
(\mathbf{m g} / \mathbf{L})\end{array}$ & $\begin{array}{c}\text { Chloride } \\
(\mathbf{m g} / \mathbf{L})\end{array}$ \\
\hline US1 & $0.00 \pm 0.00$ & $0.01 \pm 0.00$ & $1.56 \pm 0.10$ & $27.66 \pm 1.30$ \\
US2 & $0.00 \pm 0.00$ & $0.03 \pm 0.00$ & $* 3.94 \pm 0.00$ & $54.01 \pm 0.30$ \\
DS1 & $* 0.10 \pm 0.00$ & $* 0.08 \pm 0.00$ & $* 6.50 \pm 1.10$ & $* 77.66 \pm 3.60$ \\
DS2 & $* 0.10 \pm 0.00$ & $* 0.07 \pm 0.00$ & $* 3.69 \pm 1.00$ & $46.29 \pm 3.60$ \\
\hline
\end{tabular}




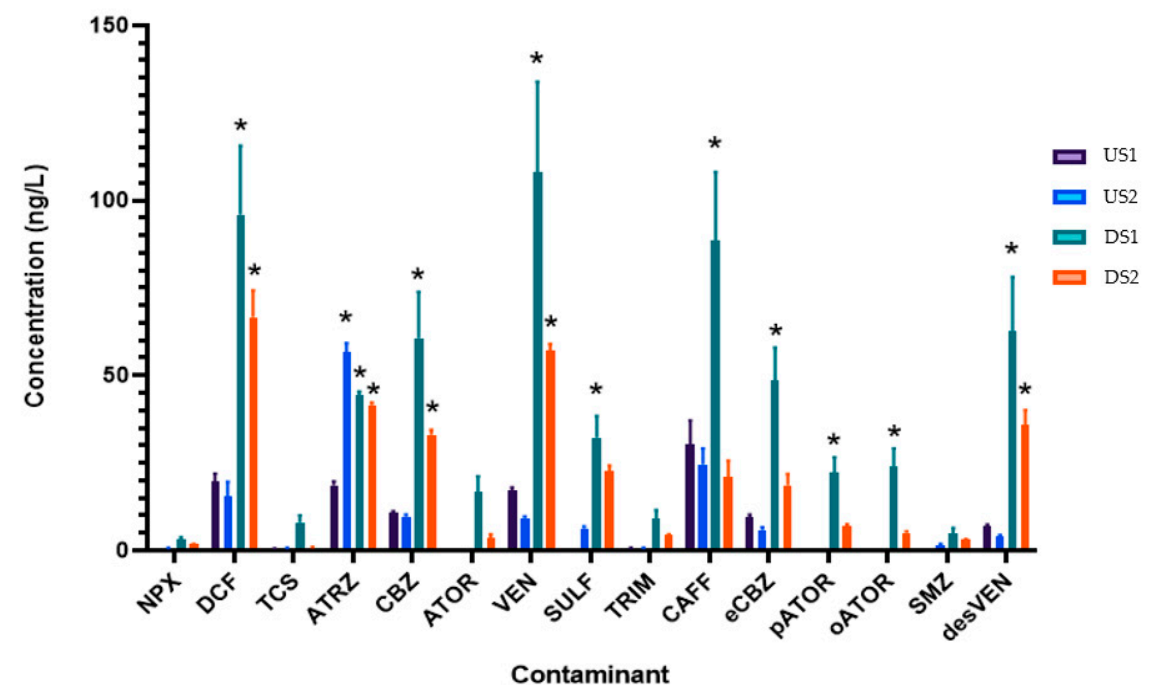

Figure 2. Pharmaceuticals and contaminants measured in the Grand River in summer 2019. Data are presented as mean \pm SEM $(n=3$ per site). Concentrations $(n g / L)$ of many pharmaceuticals and personal care products were detectable throughout the watershed but usually increased downstream from the MWWTP. Abbreviations on the x-axis from left to right: naproxen (NPX), diclofenac (DCF), triclosan (TCS), atrazine (ATRZ), carbamazepine (CBZ), atorvastatin (ATOR), venlafaxine (VEN), sulfamethoxazole (SULF), trimethoprim (TRIM), caffeine (CAFF), 11,12-epoxide carbamazepine (eCBZ), p-hydroxy atorvastatin (pATOR), o-hydroxy atorvastatin (oATOR), sulfamethazine (SMZ), desmethyl venlafaxine (desVEN). US1, upstream 1; US2, upstream 2; MWWTP, municipal wastewater treatment plant; DS1, downstream 1; DS2, downstream 2. An asterisk indicates a significant difference in concentration compared to US1 (Dunnett's multiple comparisons test, $p<0.05$ ).

\subsection{Contaminant Profile}

In summer 2019, river water samples were analyzed for key contaminants at the four sites surrounding the Waterloo MWWTP (Figure 2). There was a significant increase in diclofenac, atrazine, carbamazepine, venlafaxine, sulfamethoxazole, caffeine, 11,12-epoxide carbamazepine, p-hydroxy atorvastatin, o-hydroxy atorvastatin, and desmethyl venlafaxine at DS1 when compared to US1 $(p<0.05)$. Diclofenac, atrazine, carbamazepine, venlafaxine, and desmethyl venlafaxine persisted downstream at DS2 and were significantly increased compared to US1 $(p<0.05)$. Atrazine was significantly increased at US2 compared to US1 $(p<0.05)$.

\subsection{Body Condition}

Length, mass, and body condition are measurements of energy storage and fish health (for a summary, see Table 3). All data passed Levine's test and the Kolmogorov-Smirnov test $(p<0.05)$. In summer 2019, there were no significant differences in the RBDs' lengths in any sex at any site, compared to US1. The FTDs' lengths displayed no significant changes in any season at any site. There was a significant increase in the length of female GSDs at DS1 in summer $2019(p<0.0001)$. There were no differences between US1 and any site in RBDs' masses. There were no significant changes observed in FTDs' masses in summer 2019. The mass of female GSDs at DS1 in summer 2019 was significantly larger than US1 $(p=0.0001)$. There were no significant differences in body condition in summer 2019 for any species.

In fall 2019, there was a significant increase in the length of male RBDs $(p=0.0062)$. There were no differences in the FTDs' or GSDs' lengths between any site compared to US1, in either sex. Male RBDs were heavier at both DS1 and DS2 compared to US1 ( $p=0.002$ and $p=0.027$, respectively). There were no differences in the masses of FTDs when compared to US1. Female GSDs were smaller at US2 in fall 2019 ( $p=0.031$ ). Female RBDs had significantly increased body conditions at DS1 compared to US1 $(p=0.013)$. GSDs and FTDs did not show any differences in body condition in fall 2019. 
Table 3. Summary of the length $(\mathrm{cm})$, mass $(\mathrm{g})$, and body condition $\left(k=100 \times\left(\mathrm{m} / \mathrm{l}^{3}\right), m\right.$-mass in grams, $l$ length in $\left.\mathrm{cm}\right)$ of three darter species collected throughout the study. Data are presented as mean \pm SEM. The numbers of samples $(n)$ are presented in the sex column, in order from US1 to DS2. An asterisk indicates the average values that were significantly different (Dunnett's multiple comparisons test, $p<0.05$ ) than those found at the reference site, US1. RBD, rainbow darter; FTD, fantail darter; GSD, greenside darter; F, female; M, male; US1, upstream 1; US2, upstream 2; DS1, downstream 1; DS2, downstream 2.

\begin{tabular}{|c|c|c|c|c|c|c|c|c|c|c|c|c|c|c|}
\hline \multirow[b]{2}{*}{ Season } & \multirow[b]{2}{*}{ Species } & \multirow[b]{2}{*}{$\operatorname{Sex}(n)$} & \multicolumn{4}{|c|}{ Length (cm) } & \multicolumn{4}{|c|}{ Mass (g) } & \multicolumn{4}{|c|}{ Body Condition (k) } \\
\hline & & & US1 & US2 & DS1 & DS2 & US1 & US2 & DS1 & DS2 & US1 & US2 & DS1 & DS2 \\
\hline \multirow{6}{*}{$\begin{array}{l}\text { Summer } \\
2019\end{array}$} & RBD & $\begin{array}{c}\mathrm{F} \\
(7,7,8,8)\end{array}$ & $5.9 \pm 2.2$ & $5.6 \pm 2.1$ & $5.4 \pm 1.7$ & $5.1 \pm 2.1$ & $2.52 \pm 0.89$ & $2.47 \pm 0.87$ & $2.04 \pm 0.64$ & $1.77 \pm 0.72$ & $1.21 \pm 0.46$ & $1.32 \pm 0.49$ & $1.26 \pm 0.40$ & $1.23 \pm 0.50$ \\
\hline & & $\begin{array}{c}\mathrm{M} \\
(7,7,10,6)\end{array}$ & $5.96 \pm 2.3$ & $5.99 \pm 2.2$ & $5.79 \pm 2.05$ & $5.44 \pm 1.9$ & $3.03 \pm 1.07$ & $2.97 \pm 1.05$ & $2.75 \pm 0.97$ & $2.14 \pm 0.76$ & $1.40 \pm 0.53$ & $1.33 \pm 0.50$ & $1.40 \pm 0.50$ & $1.27 \pm 0.45$ \\
\hline & FTD & $\begin{array}{c}\mathrm{F} \\
(11,9,8,4)\end{array}$ & $5.7 \pm 2.8$ & $5.7 \pm 2.5$ & $5.7 \pm 1.5$ & $5.3 \pm 1.6$ & $1.80 \pm 0.80$ & $2.02 \pm 0.82$ & $2.20 \pm 0.59$ & $1.61 \pm 0.51$ & $0.98 \pm 0.49$ & $1.08 \pm 0.48$ & $1.22 \pm 0.33$ & $1.09 \pm 0.33$ \\
\hline & & $\begin{array}{c}\mathrm{M} \\
(4,5,14,11)\end{array}$ & $5.9 \pm 1.8$ & $5.5 \pm 1.8$ & $5.8 \pm 2.1$ & $6.1 \pm 3.1$ & $1.92 \pm 0.58$ & $1.82 \pm 0.57$ & $2.04 \pm 0.72$ & $2.45 \pm 1.23$ & $0.95 \pm 0.29$ & $1.07 \pm 0.36$ & $1.01 \pm 0.36$ & $1.07 \pm 0.54$ \\
\hline & GSD & $\begin{array}{c}\mathrm{F} \\
(6,6,12,9)\end{array}$ & $6.9 \pm 2.4$ & $7.0 \pm 2.9$ & $* 8.0 \pm 2.2$ & $7.3 \pm 3.3$ & $4.16 \pm 1.38$ & $4.00 \pm 1.41$ & $* 5.89 \pm 1.70$ & $4.68 \pm 2.09$ & $1.14 \pm 0.40$ & $1.12 \pm 0.46$ & $1.14 \pm 0.33$ & $1.19 \pm 0.53$ \\
\hline & & $\begin{array}{c}\mathrm{M} \\
(8,6,13,5)\end{array}$ & $7.7 \pm 3.1$ & $7.3 \pm 3.0$ & $7.6 \pm 2.2$ & $8.1 \pm 2.69$ & $5.47 \pm 2.07$ & $4.57 \pm 1.62$ & $5.05 \pm 1.52$ & $4.68 \pm 2.12$ & $1.20 \pm 0.5$ & $1.1 \pm 0.46$ & $1.13 \pm 0.33$ & $1.21 \pm 0.40$ \\
\hline \multirow{6}{*}{$\begin{array}{l}\text { Fall } \\
2019\end{array}$} & RBD & $\begin{array}{c}\mathrm{F} \\
(6,9,6,7)\end{array}$ & $5.2 \pm 2.1$ & $5.1 \pm 1.7$ & $5.2 \pm 2.1$ & $5.08 \pm 1.9$ & $1.54 \pm 0.63$ & $1.67 \pm 0.56$ & $1.93 \pm 0.79$ & $1.73 \pm 0.65$ & $1.08 \pm 0.44$ & $1.17 \pm 0.39$ & $* 1.27 \pm 0.52$ & $1.17 \pm 0.44$ \\
\hline & & $\begin{array}{c}\mathrm{M} \\
(8,5,8,7)\end{array}$ & $5.25 \pm 1.9$ & $5.12 \pm 2.29$ & $* 6.26 \pm 2.2$ & $6.01 \pm 2.3$ & $1.83 \pm 0.65$ & $1.69 \pm 0.75$ & $3.32 \pm 1.17$ & $2.98 \pm 1.12$ & $1.25 \pm 0.44$ & $1.17 \pm 0.53$ & $1.32 \pm 0.47$ & $1.33 \pm 0.50$ \\
\hline & FTD & $\begin{array}{c}\mathrm{F} \\
(5,4,7,6)\end{array}$ & $5.02 \pm 2.2$ & $4.63 \pm 2.3$ & $4.96 \pm 1.9$ & $4.95 \pm 2.0$ & $1.34 \pm 0.60$ & $0.96 \pm 0.48$ & $1.23 \pm 0.47$ & $1.21 \pm 0.50$ & $1.04 \pm 0.47$ & $0.92 \pm 0.46$ & $0.95 \pm 0.36$ & $0.97 \pm 0.39$ \\
\hline & & $\begin{array}{c}\mathrm{M} \\
(9,10,7,8)\end{array}$ & $5.64 \pm 1.9$ & $5.84 \pm 1.9$ & $5.70 \pm 2.2$ & $5.46 \pm 1.9$ & $1.69 \pm 0.56$ & $1.79 \pm 0.57$ & $2.06 \pm 0.78$ & $1.81 \pm 0.64$ & $0.93 \pm 0.31$ & $0.87 \pm 0.27$ & $0.98 \pm 0.37$ & $1.05 \pm 0.37$ \\
\hline & GSD & $\begin{array}{c}\mathrm{F} \\
(8,3, \mathrm{~N} / \mathrm{A}, 2)\end{array}$ & $6.75 \pm 2.4$ & $5.43 \pm 3.14$ & $\mathrm{~N} / \mathrm{A}$ & $5.65 \pm 4.0$ & $3.57 \pm 1.26$ & $* 1.58 \pm 0.91$ & N/A & $1.73 \pm 1.23$ & $1.12 \pm 0.40$ & $0.98 \pm 0.56$ & N/A & $0.94 \pm 0.67$ \\
\hline & & $\begin{array}{c}\mathrm{M} \\
(6,11,14,12)\end{array}$ & $6.05 \pm 2.5$ & $5.98 \pm 1.8$ & $5.81 \pm 1.6$ & $6.16 \pm 1.8$ & $2.57 \pm 1.05$ & $1.95 \pm 0.59$ & $2.18 \pm 0.58$ & $2.56 \pm 0.74$ & $1.03 \pm 0.42$ & $0.93 \pm 0.28$ & $1.06 \pm 0.28$ & $1.03 \pm 0.30$ \\
\hline
\end{tabular}




\subsection{Metabolic Rate}

All data passed Levine's test and the Kolmogorov-Smirnov test $(p<0.05)$. In summer 2019, the RBDs and FTDs showed significant increases in AS downstream from the MWWTP (Figure 3a). There were no significant changes in FMR, as the increase in AS observed was from an increase in MMR. Values are presented as means \pm SEM. In the RBDs, there was a significant 2.2-fold increase of AS ( $\mathrm{mg} \mathrm{O} / 2 \mathrm{~kg} / \mathrm{hr}$ ) at DS2 compared to US1 ( $p=0.0287, n=14,10,10,14$ for US1, US2, DS1, and DS2, respectively). There were no other significant differences, but a trend of increased AS at DS1 (2.1-fold; n.s.). The RBDs' AS at US2 was 0.9-fold lower than at US1. There were no significant differences in AS for the GSDs $(n=13,12,13,14)$. The AS of the GSDs was 1.2-fold higher at US2, 1.0-fold at DS1, and 1.6-fold at DS2. The FTDs $(n=11,11,11,13)$ at DS1 had a significant 2.7-fold increase in AS compared to US1 ( $p=0.013$ ). The FTDs' AS increased 1.8-fold at US2 and 1.5 at DS2, but were not statistically significant. In fall 2019 (Figure 3b), there were no statistically significant differences in FMR, MMR, or AS.

(a)

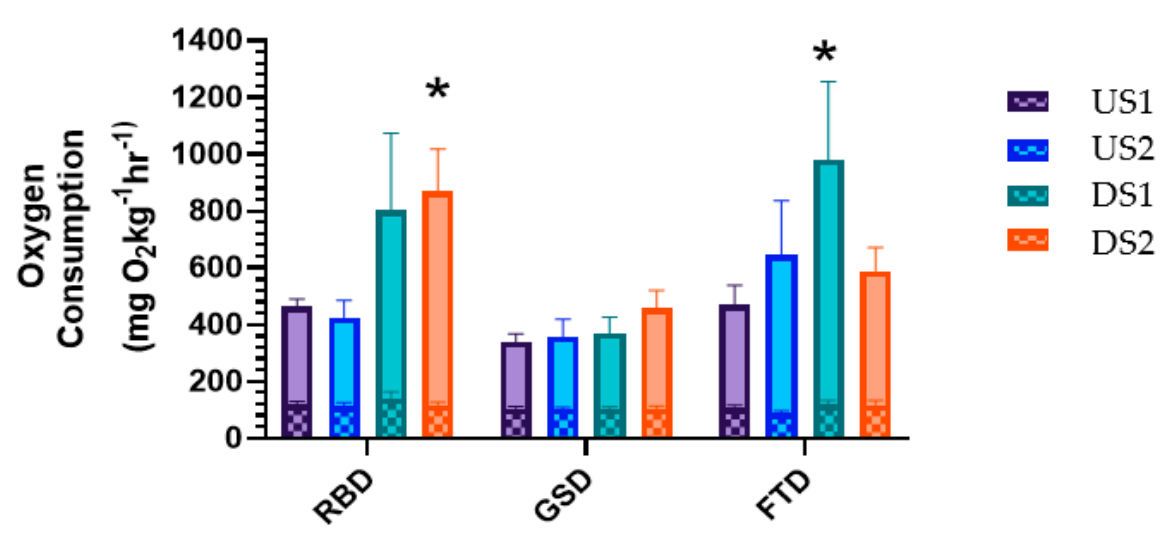

(b)

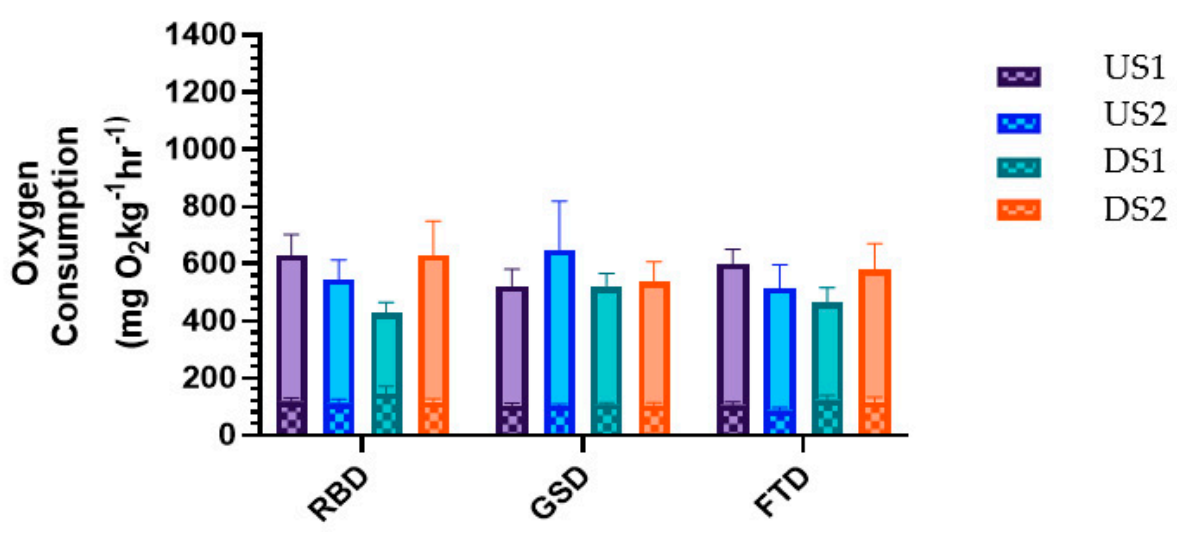

Figure 3. (a) Field metabolic rate (FMR) and maximum metabolic rate (MMR) of the RBDs, GSDs, and FTDs in summer 2019. (b) FMR and MMR of the RBDs, GSDs, and FTDs in fall 2019. Data are represented as means $\pm \mathrm{SEM}$ (oxygen consumption- $\mathrm{mg} \mathrm{O}_{2} / \mathrm{kg} / \mathrm{hr}$ ). AS is represented as the smooth area (MMR (entire bar)-FMR (checkered bar)). The Waterloo MWWTP is between US2 and DS1. An asterisk indicates a significant difference $(p<0.05)$ between US1 (reference site) and that location using Dunnett's post hoc test. RBD, rainbow darter; FTD, fantail darter; GSD, greenside darter; US1, upstream 1; US2, upstream 2; DS1, downstream 1; DS2, downstream 2. 


\subsection{Histology}

In all seasons, only the SLW, a measurement of oxygen diffusion distance, showed significant differences between the sites (Figures 4 and 5). Hyperplasia, fusion, epithelial lifting, edema, and hypertrophy were seen in samples from all sites and all years, but the severity of pathologies was most prevalent at DS1. No season or species had significant differences in SLL, BET, or ID. In 2013/2014, the RBDs showed a significantly increased SLW $(p=0.047)$ and pathologies $(p=0.038)$ at DS1. US2 and DS2 showed a trend of increased pathologies but there were no significant differences compared to US1. Overall, the most prominent pathologies were hyperplasia and fusion of the secondary lamellae. In summer 2019, there was an increase in gill lamellae diameter in the RBDs at DS1 $(p=0.019)$. There was a significant effect of the site on pathology in the RBDs (one-way ANOVA, F $=3.619$, $p=0.044)$, but no significant between-site differences. The GSDs had significantly increased lamellae diameter at DS1 $(p=0.024)$ and DS2 $(p=0.031)$ and increased pathology at US2 $(p=0.022)$ and DS1 $(p=0.049)$ in summer 2019 compared to US1.

(a)

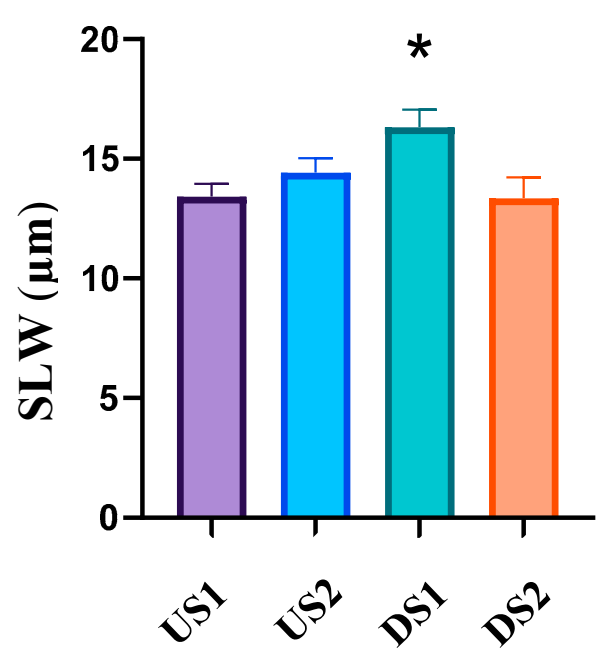

(c)

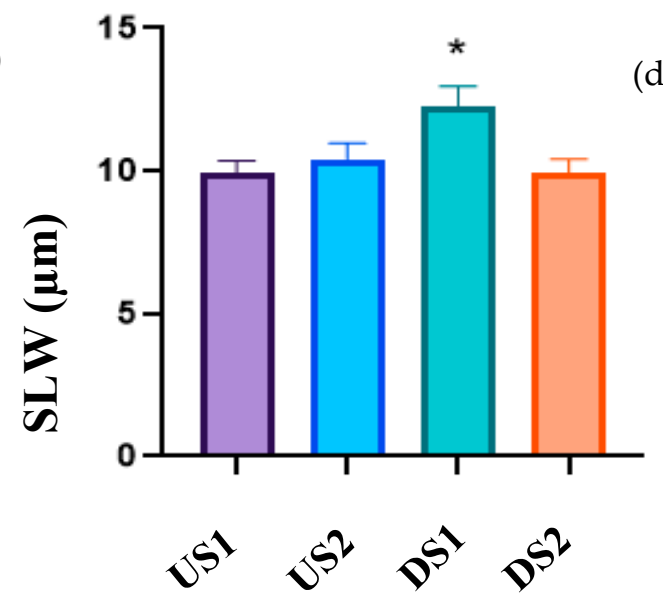

(b)
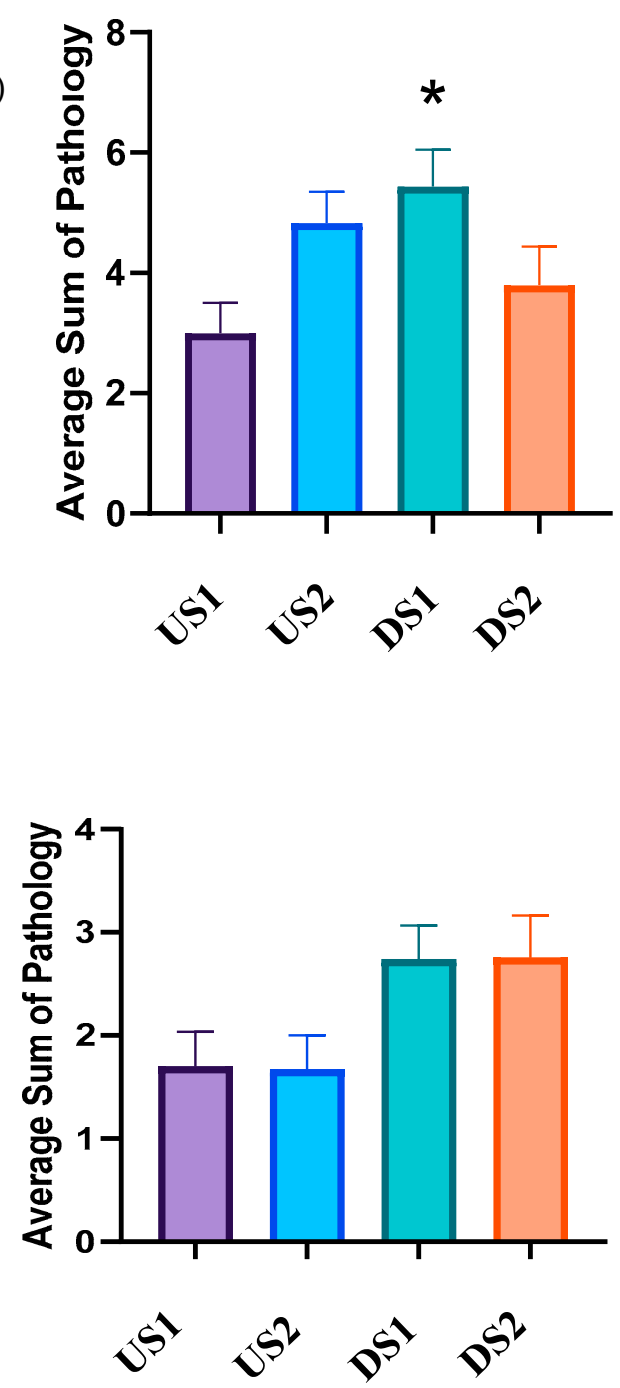

Figure 4. (a) Secondary lamellar width/diameter (SLW) of the RBDs in fall 2013/2014. (b) Pathology scores of the RBDs in fall 2013/2014 ( $p<0.05, n=8,18,16,15)$. (c) SLW of the RBDs in summer 2019. (d) Pathology scores of the RBDs in summer $2019(p<0.05, n=9,11,14,11)$. An asterisk represents a significant difference compared to US1 using a one-way ANOVA and Dunnett's multiple comparisons test. RBD, rainbow darter; US1, upstream 1; US2, upstream 2; DS1, downstream 1; DS2, downstream 2. 

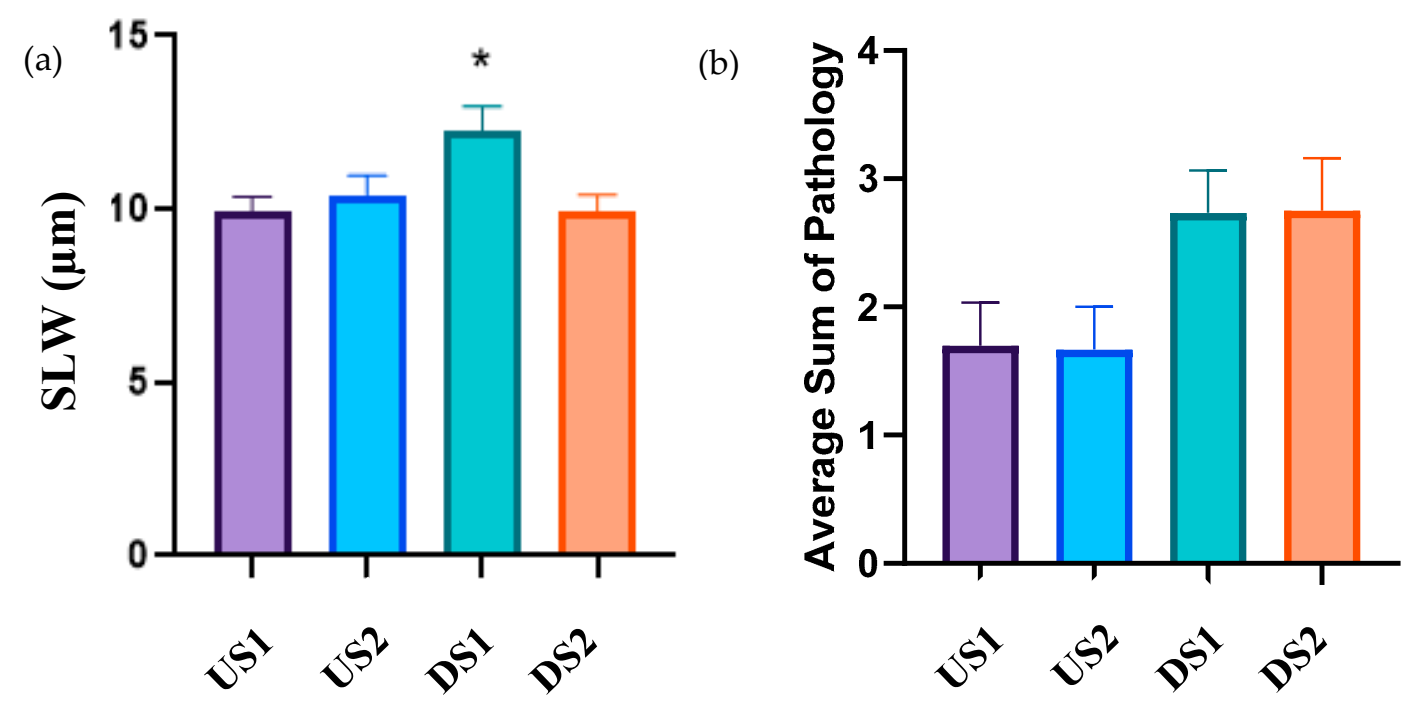

Figure 5. (a) The average SLW of the GSDs in summer $2019(p<0.05, n=11,8,24,11)$. (b) The average pathology scores of the GSDs in summer $2019(p<0.05, n=11,8,24,11)$. An asterisk represents a significant difference compared to US1 using a one-way ANOVA and Dunnett's multiple comparisons test. GSD, greenside darter; US1, upstream 1; US2, upstream 2; DS1, downstream 1; DS2, downstream 2.

\section{Discussion}

The Waterloo MWWTP process upgrades included an increased solids retention time, added aeration/nitrification process, and UV disinfection, which improves effluent quality and odor and improved process efficiency. This upgrade followed guidelines set by the Fisheries Act Canada and the Ministry of Justice in 2012, requiring all MWWTPs to be upgraded to at least secondary treatment. The upgrades took place from 2009 until 2018; these measures were implemented to reduce $\mathrm{BOD}$, TSS, and chlorine and ammonia levels. Although upgrades to the Waterloo MWWTP occurred prior to this study, there were measurable amounts of pharmaceuticals and personal care products detectable throughout the Grand River, where the levels increased downstream from the MWWTP (Figure 2). Of the highest contaminant concentrations detected, carbamazepine (antiepileptic), diclofenac (anti-inflammatory), and venlafaxine (antidepressant) were persistent pharmaceuticals that are not easily broken down and remain at high concentrations after release into the river, even after upgrades to the MWWTP $[12,44,45]$. Concentration limits for effects of CECs are difficult to set due to the potential synergistic, antagonistic, or additive effects of contaminant combinations $[46,47]$. Although concentrations have significantly decreased compared to pre-upgrade concentrations, they may still have the potential to cause sub-lethal effects on fish populations [12,48]. In the summer, there is a decrease in the flow in the river and this may be exposing the fishes downstream to a higher concentration of contaminants than in other seasons due to less dilution [49]. Tables 1 and 2 demonstrate that seasonal variance caused changes throughout the river. Responses documented at US2 and DS2 may indicate that fish were responding to other stressors upstream, such as non-point sources of agricultural and urban inputs. These inputs should be considered for future studies, as effects can be hard to differentiate from the MWWTP inputs [1,48].

There were no significant changes in the FMR in any species, site, or season. RBDs could modulate their metabolic rate in response to living in effluent but perhaps the improvement in treatment has reduced their need for detoxification (lower ammonia and contaminant levels) [4]. The metabolic rates measured in this study were in the range of those of other fishes that are closely related [50]. Round Goby showed no increase in routine metabolic rate when exposed to effluent and is thought to be quite tolerant of MWWTP effluent [51]. In contrast, bluegill sunfish had an increased FMR when exposed to effluent [52]. Therefore, because the hypothesized response to effluent (i.e., contaminant) exposure was not seen, the effects of the MWWTP may have been reduced due to the upgrades. 
Recently, Martin et al. demonstrated that field-realistic exposure to an antidepressant (fluoxetine) disrupted foraging and aggression in mosquitofish [53]. While there may be no change in routine metabolism, a change in behavior could free up enough energy for detoxification and maintenance functions [54,55]; however, this remains to be studied for darter species found in the Grand River.

The aerobic scope was increased in RBDs and FTDs at DS1 and DS2 in summer 2019; additionally, there is some evidence of increased body measurements downstream from the MWWTP. Increased energy availability in fish exposed to effluent could help to explain the increase in AS $[23,56]$. Consistently higher temperatures or oxygen availability are possible explanations for the increase in MMR, which caused the change in AS, at DS1 and DS2 in RBDs and FTDs (Table 1). The DO and temperature may also vary in the microhabitats the darters live in, permitting an increase in oxygen availability [57,58]. Rummer et al. demonstrated that in spiny damselfish, Acanthochromis polyacanthus, AS increased in fish that were exposed to environmental perturbations, contrary to the expected decrease when faced with an environmental challenge [59]. Sunfish (Lepomis gibbosus) can vary their hematocrit levels, altering their ability to transport oxygen to the tissues, which may explain how the fish downstream from the MWWTP are compensating to increase their MMR [60]. Fishes can also increase perfusion and recruitment of the gills to increase MMR [28]. Darters may be utilizing these strategies to increase metabolic capacities.

Darters preferentially select water temperatures just above $20^{\circ} \mathrm{C}$, which may explain why there is an increase in their aerobic capacity in the summer over the fall [61]. Additionally, the food and habitat resources of darters overlap, causing intraspecific competition, specifically between RBDs and FTDs [62]. These two species are closely related and have similar prey; in the summer they may be similarly affected by ecological variability and therefore more sensitive to environmental upsets due to additional stressors [63]. Since GSDs do not face the same degree of competition, the metabolic adjustments may not be necessary. Alternatively, GSDs are more sensitive to changes in oxygen availability and temperature preferences, and therefore, have less ability to modify aerobic capacity [57,64]. Regardless, the evidence presented here does suggest there were differential species-specific responses to living in MWWTP effluent contaminated sites.

Damage due to contaminants can directly change the morphology of the gills, for example, epithelial lifting when toxic substances interact with the gills [65]. The most common pathologies associated with chronic, sublethal exposure to various xenobiotics are hyperplasia, edema, and cell proliferation [66]. The gills in this study demonstrated evidence of pathologies at all sites, but a significant increase in the presence and severity, as well as thickened lamellar epithelium, was found at the sites downstream from the MWWTP in RBDs before the upgrades. After the upgrades, there was no evidence of increased pathologies in RBDs compared to the reference site, which may indicate that the water quality has improved, which reduced the response of the gills to irritants in the water. Overall, the pathologies are thought to be defense mechanisms of the fish to limit the entry of irritants as a general stress response rather than a contaminant-specific reaction [30]. Thickening of the epithelium, hyperplasia, and epithelial lifting all increase the oxygen diffusion distance but may provide a barrier to entry for contaminants $[43,67]$. Increased water temperatures and decreased water quality due to lower flow during the summer can cause an increase in pollutant toxicity, which can explain the response of the gill morphology [68,69]. All three species have an epithelium that is already "thick" due to being benthic [28]. An increase in SLW due to hyperplasia causes gill fusion, which hinders oxygen uptake and decreases carbon dioxide offloading, making this maladaptive [70,71]. Over time, fish can resist the effects of contaminants if they are at sublethal concentrations via physiological modifications, for example, varying perfusion of the gills, increased respiration, increasing detoxification processes, or stimulating the immune system $[67,69,72]$. Overall, there was evidence of pollution effects on the gill morphology of RBDs, and in one season, on GSDs, while FTDs did not show any maladaptive response.

These results indicate that fishes could acclimate to effluent and urban contaminated water through respiratory adjustments and the improvements in water quality were reflected in reduced gill pathologies. This study provides evidence of increased metabolic capacity, even though there are 
modifications to gill tissue. Cumming \& Herbert tested the ability of damaged gills to uptake oxygen and found there was no impairment on any metabolic endpoint, despite the increase in oxygen diffusion distance, which had previously been assumed [73]. Oxygen consumption adjustments, such as changes to blood or cardiac physiology, may have compensated for the effects of contaminant exposure and even improved the oxygen uptake ability, but this needs to be further investigated [74]. There is evidence that fishes have excess lamellae that are not perfused unless required, which is called lamellar recruitment [75]. It is possible that the fishes are increasing lamellar perfusion, thereby increasing their oxygen uptake ability due to an increase in the functional surface area of the gills, in combination with other adjustments [76]. Thus, gill physiological endpoints are useful in monitoring water quality but are not necessarily an indicator of how fishes are acclimating to their environment due to there being no evidence seen here on the impact on oxygen uptake ability.

\section{Conclusions}

The purpose of these experiments was to investigate the response of darters (rainbow darter, greenside darter, and fantail darter) to Waterloo municipal wastewater treatment plant effluent in the Grand River after upgrading to secondary treatment with an increased solids retention time and nitrification. These upgrades were hypothesized to reduce the biological impacts on fishes downstream, as seen after upgrades to a second municipal wastewater treatment plant in the Waterloo region $[12,48]$. Rainbow darters had a reduced intersex severity downstream of the Waterloo outfall after the upgrades to the treatment plant [77]. Improving municipal wastewater treatment plants to tertiary treatment to reduce the biological impacts on darters downstream is supported.

This study aimed to characterize the metabolic and gill tissue responses of darters exposed to the improved Waterloo municipal wastewater treatment plant effluent and compare them to fish populations upstream of the outfall. However, rainbow and fantail darters showed an increased maximum metabolic rate, and therefore, an increased aerobic scope. Greenside darters were unaffected. Rainbow and fantail darters' sizes were unaltered when metabolic adjustments were seen, while the greenside darters were significantly larger and did not alter their aerobic scope, indicating that species-specific differences in metabolic adjustments may be occurring. Overall, there is no clear pattern in the impacts of the municipal wastewater treatment plant effluent or detrimental effects of effluent (i.e., contaminants) due to the variation in the darter's physiological responses at the various sites. The increased aerobic scope and body measurements indicate that fish living in the urbanized areas of the Grand River may have utilized the greater nutrient (i.e., food) and oxygen availability. Additionally, there were effects of effluent on the gill morphology of darters found in the Grand River. The results were not consistent across seasons, sites, or species, which should be considered in future studies. However, the evidence presented here suggests there were species-specific responses to changing water quality conditions. This study highlights potential effects and markers of contaminant exposure and the importance of looking at multiple species when assessing contaminant effects.

Author Contributions: Conceptualization, R.H., M.R.S., and P.M.C.; methodology, R.H., L.B., H.A.D., and P.M.C.; software, R.H. and L.B.; validation, R.H., L.B., H.A.D., and P.M.C.; formal analysis, R.H.; investigation, R.H., L.B., and H.A.D.; resources, L.B., H.A.D., M.R.S., and P.M.C.; data curation, R.H.; writing-original draft preparation, R.H.; writing - review and editing, R.H., M.R.S., and P.M.C.; visualization, R.H.; supervision, P.M.C.; project administration, M.R.S. and P.M.C.; funding acquisition, R.H., M.R.S., and P.M.C. All authors have read and agreed to the published version of the manuscript.

Funding: This research was supported through the Natural Science and Engineering Research Council (\#RGPIN-2015-05643) and the Canadian First Research Excellence Fund Global Water Futures initiative (PI: Mark Servos). R.H. was supported by a Queen Elizabeth II Graduate Scholarship in Science and Technology.

Conflicts of Interest: The authors declare no conflict of interest. 


\section{Appendix A}

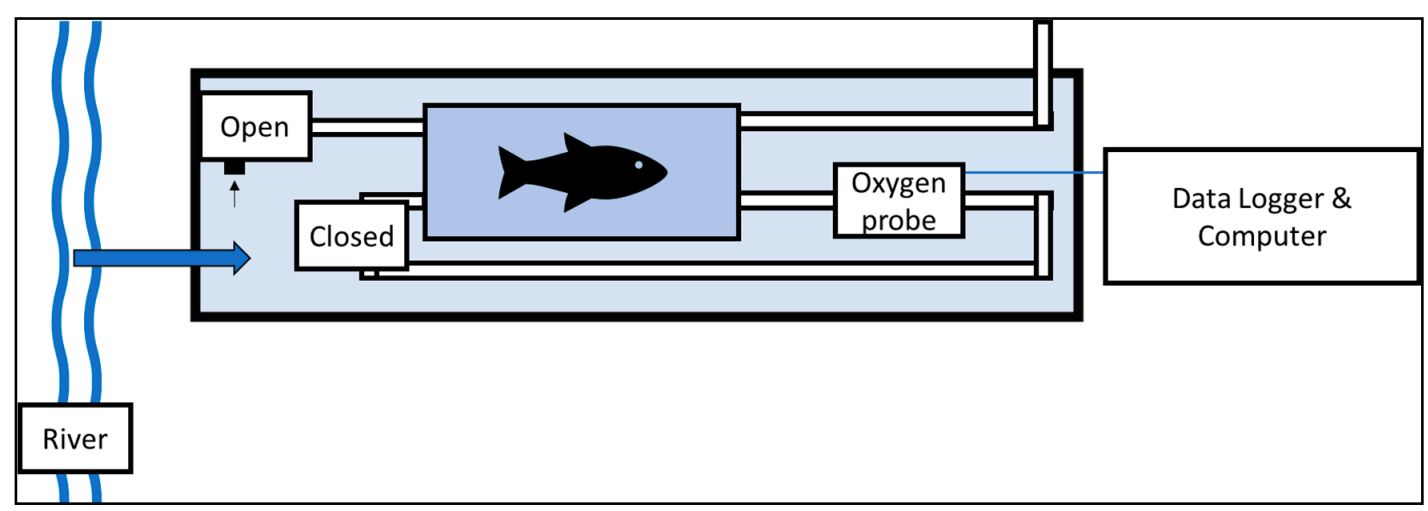

Figure A1. The respirometry set up in the field. River water was pumped directly into a reservoir where an "open" loop pump moved water through the chambers with oxygenated water for acclimation. During measurement, the "open" pump was closed off and the "closed" pump continued to circulate water through the device while the fish's respiration was recorded by the oxygen probe and sent to the data logger and computer.

Table A1. Gill pathology scoring descriptions. The description of the five common pathologies that were scored in each histological sample. An average score of all pathologies was taken from the sum of each sample at each site and compared to the reference site's average to test for differences.

\begin{tabular}{ccc}
\hline Pathology & Score & Description \\
\hline Hypertrophy & 1 & 1-2 cells swollen \\
& 2 & Swollen cells on multiple lamellae \\
& 3 & Multiple affected cells on many lamellae \\
& 4 & Most lamellae have many affected cells \\
\hline Hyperplasia & 1 & Some lamellae (1-5) show hyperplasia \\
& 2 & Most lamellae have some hyperplasia \\
& 3 & All lamellae show hyperplasia, beginning to fuse \\
& 4 & Lamellae are indistinguishable and all have severe hyperplasia \\
\hline Epithelial Lifting & 1 & Mild lifting at the base of the lamellae on 1-2 \\
& 2 & 3-5 lamellae showing minor lifting \\
& 3 & Many lamellae have lifted epithelium moving to the tip \\
& 4 & Lamellae are lifted on the entirety of the lamellae and on most to all \\
\hline Lamellar fusion & 1 & 1-2 lamellae are fused/overlapping \\
& 2 & Fusion of the many tips of lamellae \\
& 3 & Most of the lamellae are completely fused, otherwise tips fused \\
& 4 & There are no distinguishable parts of lamellae, all fused \\
\hline Edema & 1 & One or two lamellae are mildly swollen \\
& 2 & 1-4 lamellae are more severely swollen, very blown up \\
& 3 & 4+ lamellae are affected, 1-2 are severe \\
& 4 & Many lamellae are completely swollen to the filament base. \\
& & At least 3+ are severe \\
\hline
\end{tabular}




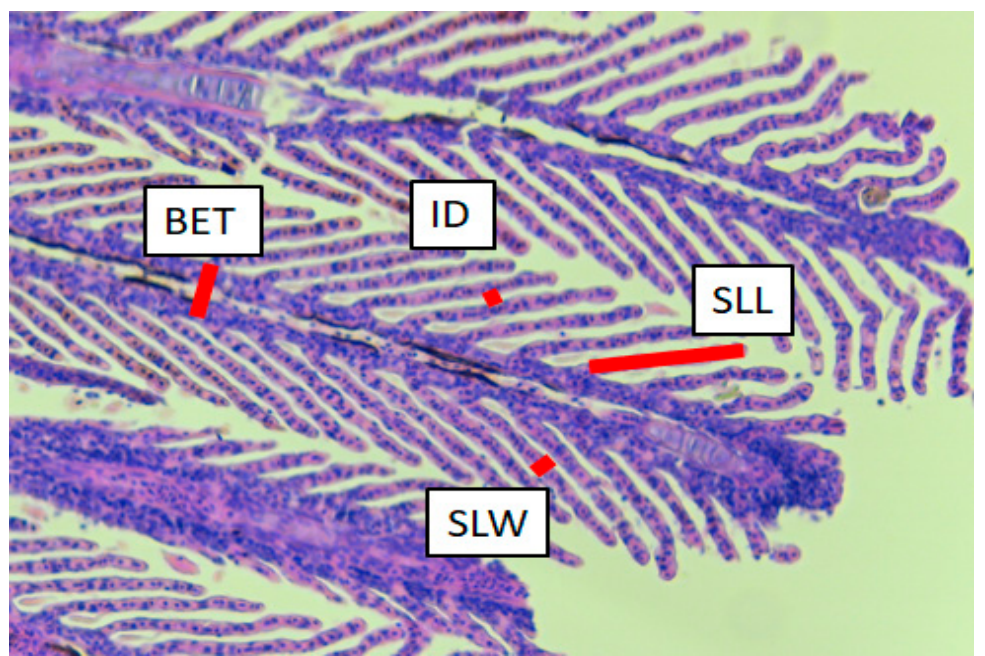

(a)

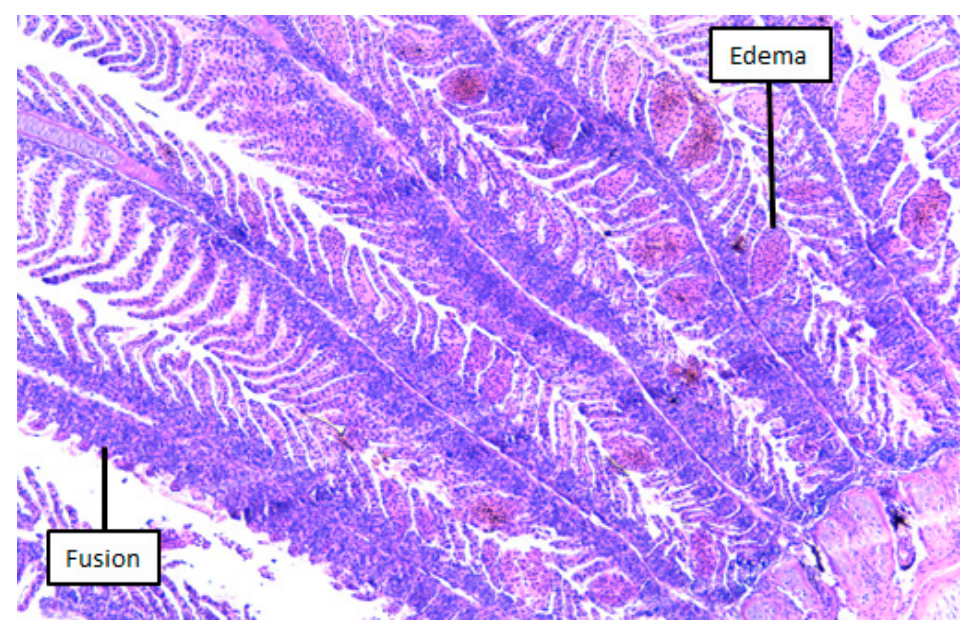

(b)

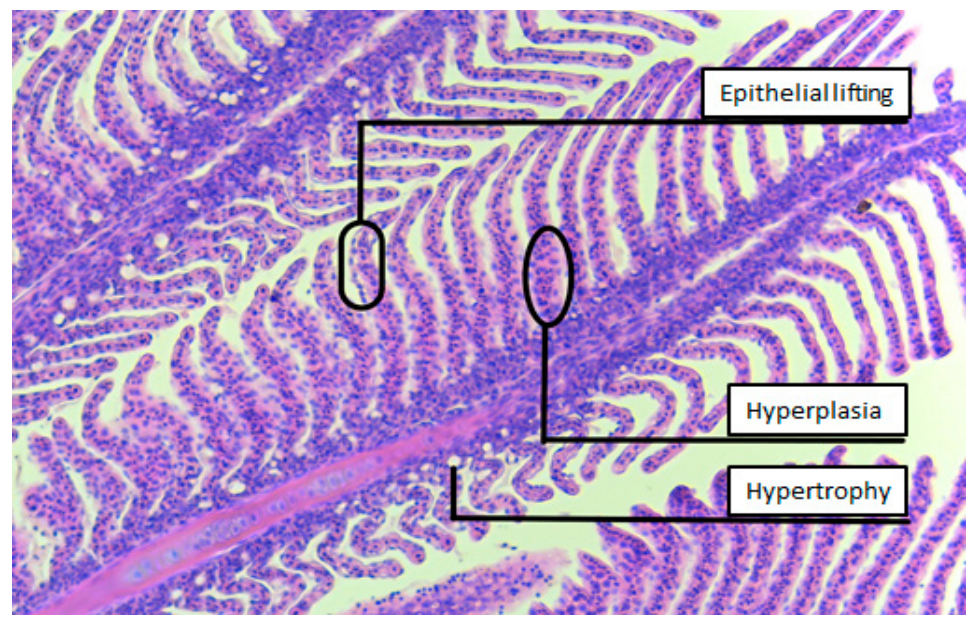

(c)

Figure A2. (a) Sample of morphometric measurements of the gill. BET, basal epithelium thickness; ID, interlamellar diameter; SLL, secondary lamellar length; SLW, secondary lamellar width. $(\mathbf{b}, \mathbf{c})$. Examples of the gill pathologies that were scored. Five pathologies were scored out of a scale from 1-4 for severity and summed, where (b) shows edema and fusion of the secondary lamellae and (c) shows epithelial lifting, hyperplasia, and hypertrophy. See methods and Table A1 for descriptions of the pathologies. 


\section{References}

1. Park, M.; Park, M.-H. Evaluation of Watershed Susceptibility to Contaminants of Emerging Concern. J. Am. Water Works Assoc. 2015, 107, E174-E186. [CrossRef]

2. Overturf, M.D.; Anderson, J.C.; Pandelides, Z.; Beyger, L.; Holdway, D.A. Pharmaceuticals and personal care products: A critical review of the impacts on fish reproduction. Crit. Rev. Toxicol. 2015, 45, 469-491. [CrossRef] [PubMed]

3. Bahamonde, P.A.; Fuzzen, M.L.; Bennett, C.J.; Tetreault, G.R.; McMaster, M.E.; Servos, M.R.; Martyniuk, C.J.; Munkittrick, K.R. Whole organism responses and intersex severity in rainbow darter (Etheostoma caeruleum) following exposures to municipal wastewater in the Grand River basin, ON, Canada. Part A. Aquat. Toxicol. 2015, 159, 290-301. [CrossRef] [PubMed]

4. Mehdi, H.; Dickson, F.H.; Bragg, L.M.; Servos, M.R.; Craig, P.M. Impacts of wastewater treatment plant effluent on energetics and stress response of rainbow darter (Etheostoma caeruleum) in the Grand River watershed. Comp. Biochem. Physiol. Part B Biochem. Mol. Biol. 2018, 224, 270-279. [CrossRef] [PubMed]

5. Fuzzen, M.L.M.; Bragg, L.M.; Tetreault, G.R.; Bahamonde, P.A.; Tanna, R.N.; Bennett, C.J.; McMaster, M.E.; Servos, M.R. An assessment of the spatial and temporal variability of biological responses to municipal wastewater effluent in rainbow darter (Etheostoma caeruleum) collected along an urban gradient. PLoS ONE 2016, 11, e0164879. [CrossRef]

6. Hicks, K.A.; Fuzzen, M.L.M.; McCann, E.K.; Arlos, M.J.; Bragg, L.M.; Kleywegt, S.; Tetreault, G.R.; McMaster, M.E.; Servos, M.R. Reduction of Intersex in a Wild Fish Population in Response to Major Municipal Wastewater Treatment Plant Upgrades. Environ. Sci. Technol. 2017, 51, 1811-1819. [CrossRef]

7. Arlos, M.J.; Parker, W.J.; Bicudo, J.R.; Law, P.; Hicks, K.A.; Fuzzen, M.L.M.; Andrews, S.A.; Servos, M.R. Modeling the exposure of wild fish to endocrine active chemicals: Potential linkages of total estrogenicity to field-observed intersex. Water Res. 2018, 139, 187-197. [CrossRef]

8. Chambers, P.A.; Allard, M.; Walker, S.L.; Marsalek, J.; Lawrence, J.; Servos, M.; Busnarda, J.; Munger, K.S.; Adare, K.; Jefferson, C.; et al. Impacts of municipal wastewater effluents on Canadian waters: A review. Water Qual. Res. J. Canada 1997, 32, 659-713. [CrossRef]

9. Cooke, S. Water Quality in the Grand River: A Summary of Current Conditions (2000-2004) and Long Term Trends. Grand River Conservation Authority. 2006. Volume 17. Available online: https://www. grandriver.ca/en/our-watershed/resources/Documents/Water_Quality_Conditions_2006.pdf (accessed on 25 November 2020).

10. CCME. Canada-Wide Strategy for the Management of Municipal Wastewater Effluent-2014 Progress Report; Canadian Council of Ministers of the Environment: Victoria, BC, Canada, 2014.

11. Government of Canada Wastewater Systems Effluent Regulations: SOR/2012-139. Government Canada Justice Laws Website. 2016. Volume 66. Available online: https://laws-lois.justice.gc.ca/eng/regulations/sor2012-139/fulltext.html (accessed on 25 November 2020).

12. Srikanthan, N. Analysis of Temporal Changes in Estrogenic Compounds Released from Municipal Wastewater Treatment Plants. Master's Thesis, University of Waterloo, Waterloo, ON, Canada, 2019; p. 122.

13. Carey, R.O.; Migliaccio, K.W. Contribution of wastewater treatment plant effluents to nutrient dynamics in aquatic systems. Environ. Manag. 2009, 44, 205-217. [CrossRef]

14. Tsai, C.-F. Water Quality and Fish Life below Sewage Outfalls. Trans. Am. Fish. Soc. 1973, 102, 281-292. [CrossRef]

15. Water Quality Working Group. Grand River Water Management Plan 2013 Update Sources of Nutrients and Sediments in the Grand River Watershed; Water Quality Working Group: Cambridge, ON, Canada, 2013.

16. Camargo, M.M.P.; Martinez, C.B.R. Histopathology of gills, kidney and liver of a Neotropical fish caged in an urban stream. Neotrop. Ichthyol. 2007, 5, 327-336. [CrossRef]

17. Gomez Isaza, D.F.; Cramp, R.L.; Franklin, C.E. Living in polluted waters: A meta-analysis of the effects of nitrate and interactions with other environmental stressors on freshwater taxa. Environ. Pollut. 2020, 261, 114091. [CrossRef] [PubMed]

18. Brooks, B.W.; Riley, T.M.; Taylor, R.D. Water quality of effluent-dominated ecosystems: Ecotoxicological, hydrological, and management considerations. Hydrobiologia 2006, 556, 365-379. [CrossRef]

19. Adams, S.M.; Greeley, M.S. Ecotoxicological indicators of water quality: Using multi-response indicators to assess the health of aquatic ecosystems. Water. Air. Soil Pollut. 2000, 123, 103-115. [CrossRef] 
20. Diamond, S.R.; Sultana, T.; Servos, M.R.; Metcalfe, C.D. Biological responses to contaminants in darters (Etheostoma spp.) collected from rural and urban regions of the Grand River, ON, Canada. Comp. Biochem. Physiol. Part - B Biochem. Mol. Biol. 2016, 199, 126-135. [CrossRef] [PubMed]

21. Barton, B.A.; Iwama, G.K. Physiological changes in fish from stress in aquaculture with emphasis on the response and effects of corticosteroids. Annu. Rev. Fish Dis. 1991, 1, 3-26. [CrossRef]

22. Vijayan, M.M.; Aluru, N.; Leatherland, J.F. Stress Response and the Role of Cortisol. Fish Dis. Disord. 2010, 2, 182-201.

23. Tetreault, G.R.; Bennett, C.J.; Shires, K.; Knight, B.; Servos, M.R.; McMaster, M.E. Intersex and reproductive impairment of wild fish exposed to multiple municipal wastewater discharges. Aquat. Toxicol. 2011, 104, 278-290. [CrossRef]

24. McCallum, E.S.; Nikel, K.E.; Mehdi, H.; Du, S.N.N.; Bowman, J.E.; Midwood, J.D.; Kidd, K.A.; Scott, G.R.; Balshine, S. Municipal wastewater effluent affects fish communities: A multi-year study involving two wastewater treatment plants. Environ. Pollut. 2019, 252, 1730-1741. [CrossRef]

25. Beyers, D.W.; Rice, J.A.; Clements, W.H.; Henry, C.J. Estimating physiological cost of chemical exposure: Integrating energetics and stress to quantify toxic effects in fish. Can. J. Fish. Aquat. Sci. 1999, 56, 814-822. [CrossRef]

26. Claireaux, G.; Lefrançois, C. Linking environmental variability and fish performance: Integration through the concept of scope for activity. Philos. Trans. R. Soc. B Biol. Sci. 2007, 362, 2031-2041. [CrossRef]

27. Treberg, J.R.; Killen, S.S.; MacCormack, T.J.; Lamarre, S.G.; Enders, E.C. Estimates of metabolic rate and major constituents of metabolic demand in fishes under field conditions: Methods, proxies, and new perspectives. Comp. Biochem. Physiol. Part A Mol. Integr. Physiol. 2016, 202, 10-22. [CrossRef] [PubMed]

28. Evans, D.H.; Piermarini, P.M.; Choe, K.P. The multifunctional fish gill: Dominant site of gas exchange, osmoregulation, acid-base regulation, and excretion of nitrogenous waste. Physiol. Rev. 2005, 85, 97-177. [CrossRef] [PubMed]

29. Wendelaar Bonga, S.E.; Lock, R.A.C. Toxicants and osmoregulation in fish. Netherlands J. Zool. 1991, 42, 478-493. [CrossRef]

30. Evans, D.H. The fish gill: Site of action and model for toxic effects of environmental pollutants. Environ. Health Perspect. 1987, 71, 47-58. [CrossRef] [PubMed]

31. Reis-Santos, P.; McCormick, S.D.; Wilson, J.M. Ionoregulatory changes during metamorphosis and salinity exposure of juvenile sea lamprey (Petromyzon marinus L.). J. Exp. Biol. 2008, 211, 978-988. [CrossRef]

32. Bernet, D.; Schmidt-Posthaus, H.; Wahli, T.; Burkhardt-Holm, P. Effects of wastewater on fish health: An integrated approach to biomarker responses in brown trout (Salmo trutta L.). J. Aquat. Ecosyst. Stress Recover. 2000, 8, 143-151. [CrossRef]

33. Liney, K.E.; Hagger, J.A.; Tyler, C.R.; Depledge, M.H.; Galloway, T.S.; Jobling, S. Health effects in fish of long-term exposure to effluents from wastewater treatment works. Environ. Health Perspect. 2006, 114, 81-89. [CrossRef]

34. Du, S.N.N.; McCallum, E.S.; Vaseghi-Shanjani, M.; Choi, J.A.; Warriner, T.R.; Balshine, S.; Scott, G.R. Metabolic Costs of Exposure to Wastewater Effluent Lead to Compensatory Adjustments in Respiratory Physiology in Bluegill Sunfish. Environ. Sci. Technol. 2018, 52, 801-811. [CrossRef]

35. Farrell, A.P.; Kennedy, C.J.; Kolok, A. Effects of wastewater from an oil-sand-refining operation on survival, hematology, gill histology, and swimming of fathead minnows. Can. J. Zool. 2004, 82, 1519-1527. [CrossRef]

36. Corbett, P.A.; King, C.K.; Stark, J.S.; Mondon, J.A. Direct evidence of histopathological impacts of wastewater discharge on resident Antarctic fish (Trematomus bernacchii) at Davis Station, East Antarctica. Mar. Pollut. Bull. 2014, 87, 48-56. [CrossRef] [PubMed]

37. Hicks, K.A.; Servos, M.R. Site fidelity and movement of a small-bodied fish species, the rainbow darter (Etheostoma caeruleum): Implications for environmental effects assessment. River Res. Appl. 2017, 33, 1016-1025. [CrossRef]

38. Mochnacz, N.J.; Kissinger, B.C.; Deslauriers, D.; Guzzo, M.M.; Enders, E.C.; Anderson, W.G.; Docker, M.F.; Isaak, D.J.; Durhack, T.C.; Treberg, J.R. Development and testing of a simple field-based intermittent-flow respirometry system for riverine fishes. Conserv. Physiol. 2017, 5. [CrossRef] [PubMed]

39. Roche, D.G.; Binning, S.A.; Bosiger, Y.; Johansen, J.L.; Rummer, J.L. Finding the best estimates of metabolic rates in a coral reef fish. J. Exp. Biol. 2013, 216, 2103-2110. [CrossRef] [PubMed] 
40. Gillooly, J.F.; Brown, J.H.; West, G.B.; Savage, V.M.; Charnov, E.L. Effects of size and temperature on metabolic rate. Science 2001, 293, 2248-2251. [CrossRef]

41. Tetreault, G.R.; Bennett, C.J.; Cheng, C.; Servos, M.R.; McMaster, M.E. Reproductive and histopathological effects in wild fish inhabiting an effluent-dominated stream, Wascana Creek, SK, Canada. Aquat. Toxicol. 2012, 110-111, 149-161. [CrossRef]

42. Schindelin, J.; Arganda-Carreras, I.; Frise, E.; Kaynig, V.; Longair, M.; Pietzsch, T.; Preibisch, S.; Rueden, C.; Saalfeld, S.; Schmid, B.; et al. Fiji: An open-source platform for biological-image analysis. Nat. Methods 2012, 9, 676-682. [CrossRef]

43. Poleksic, V.; Mitrovic-Tutundzic, V. Fish gills as a monitor of sublethal and chronic effects of pollution. Sublethal Chronic Eff. Pollut. Freshw. Fish 1994, 339-352.

44. Tran, N.H.; Gin, K.Y.H. Occurrence and removal of pharmaceuticals, hormones, personal care products, and endocrine disrupters in a full-scale water reclamation plant. Sci. Total Environ. 2017, 599-600, 1503-1516. [CrossRef]

45. Vieno, N.; Sillanpää, M. Fate of diclofenac in municipal wastewater treatment plant-A review. Environ. Int. 2014, 69, 28-39. [CrossRef]

46. Coors, A.; De Meester, L. Synergistic, antagonistic and additive effects of multiple stressors: Predation threat, parasitism and pesticide exposure in Daphnia magna. J. Appl. Ecol. 2008, 45, 1820-1828. [CrossRef]

47. Metcalfe, C.D.; Chu, S.; Judt, C.; Li, H.; Oakes, K.D.; Servos, M.R.; Andrews, D.M. Antidepressants and their metabolites in municipal wastewater, and downstream exposure in an urban watershed. Environ. Toxicol. Chem. 2010, 29, 79-89. [CrossRef] [PubMed]

48. Marjan, P.; Martyniuk, C.J.; Fuzzen, M.L.M.; MacLatchy, D.L.; McMaster, M.E.; Servos, M.R. Returning to normal? Assessing transcriptome recovery over time in male rainbow darter (Etheostoma caeruleum) liver in response to wastewater-treatment plant upgrades. Environ. Toxicol. Chem. 2017, 36, 2108-2122. [CrossRef] [PubMed]

49. Anderson, M. ; GRWMP Assimilative Capacity Working Group. Assessment of Future Water Quality Conditions in the Grand and Speed Rivers; GRWMP Assimilative Capacity Working Group: Cambridge, ON, Canada, 2012.

50. Gonzalez, R.J.; Mcdonald, D.G. The Relationship Between Oxygen Uptake And Ion Loss In Fish From Diverse Habitats. J. Exp. Biol. 1994, 190, 95-108.

51. McCallum, E.S.; Du, S.N.N.; Vaseghi-Shanjani, M.; Choi, J.A.; Warriner, T.R.; Sultana, T.; Scott, G.R.; Balshine, S. In situ exposure to wastewater effluent reduces survival but has little effect on the behaviour or physiology of an invasive Great Lakes fish. Aquat. Toxicol. 2017, 184, 37-48. [CrossRef]

52. Du, S.N.N.; Choi, J.A.; McCallum, E.S.; McLean, A.R.; Borowiec, B.G.; Balshine, S.; Scott, G.R. Metabolic implications of exposure to wastewater effluent in bluegill sunfish. Comp. Biochem. Physiol. Part C Toxicol. Pharmacol. 2019, 224, 108562. [CrossRef]

53. Martin, J.M.; Saaristo, M.; Tan, H.; Bertram, M.G.; Nagarajan-Radha, V.; Dowling, D.K.; Wong, B.B.M. Field-realistic antidepressant exposure disrupts group foraging dynamics in mosquitofish. Biol. Lett. 2019, 15, 20190615. [CrossRef]

54. Handy, R.D.; Sims, D.W.; Giles, A.; Campbell, H.A.; Musonda, M.M. Metabolic trade-off between locomotion and detoxification for maintenance of blood chemistry and growth parameters by rainbow trout (Oncorhynchus mykiss) during chronic dietary exposure to copper. Aquat. Toxicol. 1999, 47, 23-41. [CrossRef]

55. Campbell, H.A.; Handy, R.D.; Sims, D.W. Increased metabolic cost of swimming and consequent alterations to circadian activity in rainbow trout (Oncorhynchus mykiss) exposed to dietary copper. Can. J. Fish. Aquat. Sci. 2002, 59, 768-777. [CrossRef]

56. Melvin, S.D. Short-term exposure to municipal wastewater influences energy, growth, and swimming performance in juvenile Empire Gudgeons (Hypseleotris compressa). Aquat. Toxicol. 2016, 170, 271-278. [CrossRef]

57. Hlohowskyj, I.; Wissing, T.E. Seasonal changes in low oxygen tolerance of fantail, Etheostoma flabellare, rainbow, E. caeruleum, and greenside, E. blennioides, darters. Environ. Biol. Fishes 1987, 18, 277-283. [CrossRef]

58. Claireaux, G.; Webber, D.M.; Lagardère, J.P.; Kerr, S.R. Influence of water temperature and oxygenation on the aerobic metabolic scope of Atlantic cod (Gadus morhua). J. Sea Res. 2000, 44, 257-265. [CrossRef]

59. Rummer, J.L.; Stecyk, J.A.W.; Couturier, C.S.; Watson, S.-A.; Nilsson, G.E.; Munday, P.L. Elevated CO2 enhances aerobic scope of a coral reef fish. Conserv. Physiol. 2013, 1. [CrossRef] [PubMed] 
60. Borowiec, B.G.; Crans, K.D.; Khajali, F.; Pranckevicius, N.A.; Young, A.; Scott, G.R. Interspecific and environment-induced variation in hypoxia tolerance in sunfish. Comp. Biochem. Physiol. Part A Mol. Integr. Physiol. 2016, 198, 59-71. [CrossRef] [PubMed]

61. Ingersoll, C.G.; Claussen, D.L. Temperature selection and critical thermal maxima of the fantail darter, Etheostoma flabellare, and johnny darter, E. nigrum, related to habitat and season. Environ. Biol. Fishes 1984, 11, 131-138. [CrossRef]

62. Hlohowskyj, I.; Wissing, T. Substrate Selection by Fantail (Etheostoma flabellare), Greenside (E. blennioides), and Rainbow (E. caeruleum) Darters. Ohio J. Sci. 1986, 86, 124-129.

63. Schlosser, I.J.; Toth, L.A. Niche Relationships and Population Ecology of Rainbow (Etheostoma Caeruleum) and Fantail (E. Flabellare) Darters in a Temporally Variable Environment. Oikos 1984, 42, 229. [CrossRef]

64. Hlohowskyj, I.; Wissing, T.E. Seasonal changes in the critical thermal maxima of fantail (Etheostoma flabellare), greenside (Etheostoma blennioides), and rainbow (Etheostoma caeruleum) darters. Can. J. Zool. 1985, 63, 1629-1633. [CrossRef]

65. Nascimento, A.A.; Araújo, F.G.; Gomes, I.D.; Mendes, R.M.M.; Sales, A. Fish Gills Alterations as Potential Biomarkers of Environmental Quality in a Eutrophized Tropical River in South-Eastern Brazil. Anat. Histol. Embryol. 2012, 41, 209-216. [CrossRef]

66. Mallatt, J. Fish gill structural changes induced by toxicants and other irritants: A statistical review. Can. J. Fish. Aquat. Sci. 1985, 42, 630-648. [CrossRef]

67. Flores-Lopes, F.; Thomaz, A.T. Histopathologic alterations observed in fish gills as a tool in environmental monitoring (Alterações histopatológicas observadas nas brânquias de peixes como instrumento no monitoramento ambiental). Brazilian J. Biol. 2011, 71, 179-188. [CrossRef] [PubMed]

68. Mckim, J.M.; Erickson, R.J. Environmental Impacts on the Physiological Mechanisms Controlling Xenobiotic Transfer across Fish Gills. Source Physiol. Zool. 1991, 64, 39-67. [CrossRef]

69. Schwaiger, J.; Wanke, R.; Adam, S.; Pawert, M.; Hönnen, W.; Triebskorn, R. The use of histopathological indicators to evaluate contaminant-related stress in fish. J. Aquat. Ecosyst. Stress Recover. 1997, 6, 75-86. [CrossRef]

70. Gilmour, K.M. Gas Exchange. Physiol. Fishes 1997, 101-128.

71. Wright, P.A.; Wood, C.M. Seven things fish know about ammonia and we don't. Respir. Physiol. Neurobiol. 2012, 184, 231-240. [CrossRef]

72. Claiborne, J.B.; Edwards, S.L.; Morrison-Shetlar, A.I. Gill circulation: Regulation of perfusion distribution and metabolism of regulatory molecules. J. Exp. Zool. 2002, 293, 320-335. [CrossRef]

73. Cumming, H.; Herbert, N.A. Gill structural change in response to turbidity has no effect on the oxygen uptake of a juvenile sparid fish. Conserv. Physiol. 2016, 4. [CrossRef]

74. Dussault, È.B.; Playle, R.C.; Dixon, D.G.; McKinley, R.S. Effects of sublethal, acidic aluminum exposure on blood ions and metabolites, cardiac output, heart rate, and stroke volume of rainbow trout, Oncorhynchus mykiss. Fish Physiol. Biochem. 2001, 25, 347-357. [CrossRef]

75. Nilsson, G.E. Gill remodeling in fish-A new fashion or an ancient secret? J. Exp. Biol. 2007, 210, $2403-2409$. [CrossRef]

76. Holbert, P.W.; Boland, E.J.; Olson, K.R. The Effect of Epinephrine and Acetylcholine on the Distribution of Red Cells Within the Gills of the Channel Catfish (Ictalurus Punctatus). J. Exp. Biol. 1979, 79, 135-146.

77. Nikel, K.E. Wild Fish Responses to Wastewater Treatment Plant Upgrades in the Grand River, Ontario. Master's Thesis, University of Waterloo, Waterloo, ON, Canada, 2020; pp. 1-93.

Publisher's Note: MDPI stays neutral with regard to jurisdictional claims in published maps and institutional affiliations.

(C) 2020 by the authors. Licensee MDPI, Basel, Switzerland. This article is an open access article distributed under the terms and conditions of the Creative Commons Attribution (CC BY) license (http://creativecommons.org/licenses/by/4.0/). 